\title{
Social and Environmental Accounting Reporting and Financial Performances in Ghana
}

\author{
Li KaoDui ${ }^{1}$, Zou Muyun ${ }^{1} \&$ Osei-Assibey Bonsu Mandella ${ }^{1}$ \\ ${ }^{1}$ School of Finance and Economics, Jiangsu University, Zhenjiang, China \\ Correspondence: Osei-Assibey Mandella Bonsu, School of Finance and Economics, Jiangsu University, 301, \\ Xuefu Road, Zhenjiang, 212013, Jiangsu Province, P.R. China. E-mail: thugdibae1 @ gmail.com
}

Received: January 6, 2019

Accepted: March 15, 2019

Online Published: March 20, 2019

doi:10.5539/ijef.v11n4p82

URL: https://doi.org/10.5539/ijef.v11n4p82

This article is the research result of the project "Postgraduate Research \& Practice Innovation Program of Jiangsu Province" (Project Number is SJCX17_0565).

\begin{abstract}
The paper seeks to ascertain the effects of social and environmental accounting disclosure on the financial performance of companies registered on the Ghana Stock Exchange over the period of three years from 2015 to 2017. The study similarly seeks to determine the extents of social and environmental accounting issues reported and finally document the extent to which companies included SEAR issues in their corporate strategy plan in Ghana.

The study used secondary data from a published corporate annual statements of all the registered companies on the Ghana Stock Exchange. A regression model and t-test were used to ascertain the effects of social and environmental accounting reporting on firm's financial performance. However, questionnaires and content analysis were also used in company reports as a system to measure the degree and nature of corporate social accounting reporting as maintained by the number of words disclosed over the three periods.

Results shows that there is a positive correlation between CSR score measuring the social and environmental accounting practices and the company's financial performance registered on the Ghana Stock Exchange. Thus, the effects are insignificant. However, the findings show that companies in Ghana are now hugging social and environmental accounting reporting practices since the course of adoption of SEAR was above $60 \%$ from 2015 to 2017. The positive correlation between social and environmental accounting and reporting and companies financial performance specify reliable step pace for top managers in companies grasp and embrace social and environmental accounting reporting practices in Ghana, West African countries and all developing Africa countries. The study backs to the literature and information of corporate social and environmental accounting in West Africa and all developing Africa countries. Besides, it also may be terrific to corporate institutions for comprehension of the social responsibilities be obliged to their stakeholders and community in general.
\end{abstract}

Keywords: CSR, environmental accounting, financial disclosure, cost accounting, Ghana stock exchange

\section{Introduction}

Social and environmental accounting disclosure is not an innovative concept. The field has grown extraordinarily in recent years. Social and environmental issues are now being joined up into all aspect of business operations all over the globe. According to Carroll (2000), the matter of SEA will be significant than ever as we entering into the $21^{\text {st }}$ Century. In the recent twentieth century, stakeholders in companies have requested much data relating to the impacts of firms exercises on people other than economic happenings. Subsequently, the SEA idea has turned out to be prevailing in corporate revealing and its approach has turned out to be integral to the vital administration choice of each business institutions (Crowther \& Aras, 2009).

In the United Kingdom, companies are under expanding pressure to take their SEA and reporting practices notwithstanding their financial duties. It is documented that failure to respond to the pressure could lead to a forfeiture of investor confidence, legal action and the fierceness of the nearby network. The primary objective of setting up an organization is to improve people's quality of life. With this, measures need to be put in place that regulates and reports the extent to which the companies has impacted the society from the time being. 
Accounting is the act of providing system that gathers data, analyses and interprets the information and disseminates the results to end users to make an informed socio economics decisions that could help in improving the quality of life as a whole (Deegan, 2017). The cost accounting is a very powerful tool and it has tended to report information, money profit performance to investors, governments, employees, and management and report transactions that are financial in nature.

Cost accounting systems completely preferencing the rights of the investors and have concealed this conflict of interest by taking on a submissive role. (Lehman \& Kuruppu, 2017). In fact, the cost accounting systems do not solve the incorporate issues of the societies and the organization's effect on society. In order for accounting system to be effective, systems and orientations must be transformed and achieved a role of social importance in the society and the environmental. Organizations need to center accountability to the society at large and not only to investors. Therefore, the accounting approach needs to be mounted to link the gap between organizations and the society made by cost accounting.

In Ghana, companies are rising steadily especially in telecommunications, manufacturing, oil productions and banking sectors. The industries in Ghana, which accounts for 1.50 percentage increases of GDP, which recorded 17.8 percent growth and flows of FDI during the period of 2017/2018. Ghana's economy recorded a substantial economic growth in 2017/2018 and been tag as the fastest growing economy in Africa (World Bank Organizations, 2017).

In the line of above increment in economic growth and the expansion of companies in Ghana, there is an obvious economic progress. According to (Belal \& Owen, 2007) cited by Md. Humunyu et al. 2012, the expansion of the economy can generate many important untimely effects socially, ethically and environmentally. This turned to increase demands for enhancing Social and Environmental Accounting in business practices according to Humunyu et al. (2012). Therefore, industries social and environmental tasks cannot fail to notice and doing so placed them in an advantageous position as sustainable industries, government relations improvement, and image reputation. (World Business Council for Sustainable Development, 2002). However, companies in Ghana are voluntarily occupied in reporting most social responsibility activities in their financial reports and have progressed further. Very little studies were done on the SEAR information disclosure practices in most emerging and developing countries both in Africa and Asia such as Malaysia, Thailand, Brazil and India as cited by (Deegan, 2017; Md. Humunyu et al., 2012), none has been done to ascertain the effects it has on the firm's financial performance. The study aims to ascertain the effects of Social and Environment Accounting Reporting on performance of firms in Ghana. The supporting objectives are to determine the areas of SEA issues reported and the format used in the annual financial reports of Ghanaian companies.

The rest of the study is as follows. The next paper reviews past research addressing social and environmental accounting and reporting. The third segment presents the research methodology of the study. The fourth section evaluates the findings and the last section finally draws the conclusion of the study.

\section{Literature Review}

Social and environmental accounting issues interest has grown among governmental, accountants, professional bodies, academicians and environmentalists (Owen et al., 200; Deegan, 2002; Hossain et al., 2012) as cited by Yousif et al. (2014) have paved way for definitions of SEAR. Gray et al as cited by Yousif et.al 2014 defined SEAR as the development of disseminating the social and environmental impacts of organizations economic activities to specific intrigue groups within the society at large. It includes extending the accountability of companies, beyond the usual role of providing a financial account to the investors. CSR reporting emerged from an increasing public "and societal "awareness of the role of companies in the local community and society (Isabel et al., 2018). From global viewpoint, CSR reporting is becoming more obvious, for instance, in triple bottom line reporting and the global reporting initiative (Isabel et al., 2018). As cited in Yousif et al. 2014. SEAR first started emerged as a discipline in the early 1970s (Owen, 2008). However, a number of scholars strived to grow and gives normative models designed to raise social and environmental accounting reporting practices (Ullmann, 1976).

According to the institute of Directors in South Africa, 2002, companies are not pressured when reporting purely financial activities but pressured when reporting on social activities due to the increasing significance emphasis on non-financial activities globally. Most companies give social responsibility reports in which they disclose on companies issues affecting society. However, there is still not any invariably approved theoretical framework with respect to CSR reporting in SEAR accounting literature (Deegan, 2002); as cited in (Isabel et al., 2018; Lehman \& Kuruppu, 2017) "in spite of the lack of agreement in the literature about why companies report Corporate Social Responsibility information", sections of companies are disclosing their social activities in their business annual reports on an open basis. The KPMG (2005) researched on a large scale of corporate annual 
reports of the top 100 corporate organizations in 16 countries and the top 250 Fortune 500 industries. The research established that there is a rise in the tendency of CSR disclosure over the last 13 years. In disclosing CSR information in Social and environmental accounting effects attain some interest. (Idowu and Towler, 2004; Adams, 2002. For example, CSR disclosures in SEA improves companies image, relationship with all stakeholders (Khan et al., 2009, p. 346), increases the quality of products and services, customer loyalty, etc.

\subsection{Theories of Social and Environmental Accounting}

Recently, several prior studies used legitimacy theory, stakeholder theory, accountability theory, political Economy and institutional theory as ways in theorizing the relationship between the accounting entity and its external world. In other words, these theories explained CSR reporting activities: Yousif et al. (2012) as cited in Isabella et al. (2018). It has been difficult to figure out the appropriate theory (Tilling, 2001) to explain a "phenomenon", and the prior studies on CSR disclosures uncovers that all theories are enticing reasons, none of the theories was discredited and supported reliably (Adams, 2002, p. 224; Yousif et al., 2012). However, these theoretical models are originated of as a series of skin which can be produced and made up into the interaction of association and society in a rich conception. Therefore, this study practically applied legitimacy theory, stakeholders theory, and accountability theory to dealt into why companies disclose on the CSR in Social and environmental activities. In fact, most researchers have virtually applied these theories. ; Islam and Deegan, 2007. With this, the study gives a brief discussion of these three theories, bringing the significant to the current study.

Stakeholders Theory; the theory developed and championed by R. Edward Freeman in the 1980s and since then it has gained global acceptance in business practices and in theorizing relating to CSR. It is defined as any group or a person who can affect and is affected directly or indirectly by the achievement of the firm's objectives (Wilmshurst, 2007, p. 3). Stakeholders of a firm include the following, shareholders, government, creditors, employees, customers, regulators suppliers and public interest groups. The main aspiration of a company is to the ability to achieve equilibrium of the conflicting demands of the various stakeholders in the firm. Stakeholders in Ghana are no exclusion to this groups since they might also possess intrigue in the company or might have an impact by the issues of a company.

According to Deegan et al. (2000), all stakeholders have the right to know the Social and Environmental indications of a company's operations at all times. This view was buttressed and argued by Gray et al. (1996) as cited by Yousif, 2012 that Social and environmental reporting should be revealed to all stakeholders. However, the managerial branch of stakeholder's theory propounds that organizations will adhere to those stakeholders with economic effect upon the companies. Dwyer (2003); Ratanajongkol et al. (2006, p. 69) as cited in Yousif et al. (2012) and those with no direct engagement in the organization economic activities. In a study noted in Savage et al. (1991, p. 62) but "have an intrigue in the activities of the organization" and are able "to impact it" Therefore, a social accounting based in view of stakeholders viewpoint has social esteem just on the off chance that we accept the advantage of the company and further expect that the stakeholders need can be subsumed ethically with those of the company. Thus, stakeholder theory would usher us to achieve that organizations would be directed in their disclosure of corporate social responsibility ins SEA activities either to reflect the number of their stakeholders or to discourse the benefits of a few leading ones.

The legitimate theory is a system adapted to theory, unlike stakeholder's theory, political economy theory, and accountability theory. Within a systems-oriented viewpoint, the entity is presumed to be influenced by, and in turn to have an influence upon the society in which it operates (Watts et al., 1986). It is the globally utilized theory to explaining Corporate Social Responsibility disclosure conducted by companies (Islam \& Deegan, 2007). According to O'Donovan (2002, p. 344), legitimacy theory is based on the plan that for organizations to works successfully, organizations must proceed and work within the norms and bound identifies as socially acceptable behavior.

It can be deduced that companies regularly seek "to shield" that their undertakings are allowable to the society. Wilmshurst and Frost (2000), as being legitimate. (Islam \& Deegan, 2007). Legitimate theory directly relies upon the concept of "social contract" Alphonse (2012). Specifically, organizations longevity are considered to be threatened if the society recognizes that the organization has violated its social contract. With this, whereas the society is dissatisfied that the operating of the organizations is not legitimate or authorized, the society will conceal their contract to continue operating effectively (Deegan \& Gordon, 1996, p. 192). Continually with legitimate theory, Ghanaian companies solely depend on the society to purchase its goods and therefore if the assumption and expectation of the society changes, so as the organizations too changed in order to accommodate the transformational expectations (Fiedler et al., 2002).

Accountability theory, accountability is the retort and assumption of obligations for actions, products, decisions, 
and policies which includes administration, governance, and application within the scope of the role or engagement position and surrounding the obligation to report, explain and answerable for resulting significances (Williams \& Reyes, 2006).

Gray et al. defined accountability as an act of being responsible for one's own decision or activities with the assumption of describing, justifying them when authorized to do so. Simply, it is frequently described an account-giving relationship exists between individuals.

The natures of the connections and the specialist rights to data are logically controlled by the general public in which the relationship happens. It is completely evident that some kind of correlation will happen between a company and every one of its stakeholder. Some portion of this relationship might be financial in nature and the terms dictated by the gatherings as mirroring their relative powers in the connection. The disclosure moving via the correlation will be dictated by the intensity of the gatherings to request it a power which, where it happens, could emerge from either the natural capacities or intensity of the gatherings concerned or from the administrative procedures of the general public, additionally want of the association to give it (Gray et al., 1997).

From the cursory deliberation, stakeholder, legitimate and accountability theories tend to achieve similar ideas. According to most researchers (Humayun \& Akinnusi, 2012), stakeholders theory emphasized on the power of stakeholders whilst legitimates theory emphasized on the desires of the society as a whole but accountability theory focus on the relationship between the organizations and the group. Hence, for the purpose of our research and with these three explained theories focused, companies in Ghana will adhere to the expectations of the society as hypothesized by legitimate theory. In response to that of stakeholders theory, "industries would be expected to loop to the stakeholders which in the long or short run might arouse against non-obeying "and there would always be a relationship between organizations and its stakeholders as postulated by accountability theory.

\subsection{Overview of Industries in Ghana}

Ghana is a country in West Africa situated between the borders of Ivory Coast and Togo, on Africa continents. Ghana is with a populace of approximately 28.2 million, (World Bank Group) and a growing economic prosperity and democratic political system have made it a national power in West Africa. (Kacowicz et. al 1998). Ghana can boast of terrific companies registered and listed on the Ghana Stock Exchange in the areas of manufacturing, taxations, oil companies, and private banking. Indeed, the economy relies strongly on exportbased good mining industries and agricultural commodities. (Central Bank of Ghana, 2016). Currently, there are 43 companies hosted on the Ghana Stock Exchange with their operations ranging from small companies to larger companies with thousands of subordinates. (Ghana Registrar of Companies, 2015). Ghana's companies have traditionally been controlled by the private sector, especially the financial sector and manufacturing sectors.

\subsection{Empirical Review}

Prior studies done out have demonstrated corporate social responsibility in the SEA is increasing.

Maunders (1982) did a survey of published accounts of 300 large companies for the year 1981 to 1982. It was revealed that the largest incidence of voluntary disclosure was in the area of human resource. Gray et al. (1995) concluded that for the various themes of social disclosures which such as environmental, community and safety the average amount of reporting had progressively increased. Cochran (1984) in his studies test the relationship between CSR activities and a firm's performance. It was shown in the study findings that, a weak, positive association exist between social responsibility activities and the firm's financial performance.

Using a sample of 101 organizations listed on the New York Security Exchange, Fauzi (2009) as cited by Alphonse (2012) conducted a study to determine the relationship between CSR and a firm's financial performance. He found out that, leverage has a diminishing impact on the relationship between CSR and firms financial performance.

Bewley and $\mathrm{Li}$ (2000) spoke to deliberate exposure hypothesis to analyze the ecological revelations of Canadian assembling firms. They utilized the Wiseman index to quantify the 1993 yearly report revelations of 188 firms and industry participants to intermediary for contamination penchant. They found that organizations with a higher contamination penchant and more noteworthy media inclusion of their natural execution will probably unveil general ecological data, an outcome likewise predictable with the socio-political speculations.

Thus, Hughes et al. (2001) inspected natural divulgences made by U.S. producing firms in 1992 and 1993 utilizing a changed Wiseman file to gauge divulgences in the president's letter, MD\&A, and notes areas of the yearly report, and the CEP rankings to intermediary for natural execution. They found that organizations evaluated as poor by the CEP, for the most part, make the most revelations. Al-Tuwaijri et al. (2004) utilized concurrent conditions way to deal with exploring the relations among ecological exposure, natural execution, 
and monetary execution. They utilized intermediary for ecological execution utilizing the level of aggregate waste produced reused as distinguished utilizing the TRI database and measure natural exposure utilizing a substance investigation in four classes, potential capable gatherings' assignment, dangerous waste, oil and synthetic spills, and natural fines and punishments, revelations which are to a great extent non-discretionary. Based on these proxies, Mogaka et al. (2004) recorded a positive association between environmental performance and environmental disclosure. It can be drawn from the above findings that, social and environmental accounting reporting issues has grown to be an interesting area of researching.

\section{Research Methodology}

\subsection{Data and Sample Section}

The study was undertaking using a correlational descriptive survey design, using both secondary data and questionnaires. The sample for the study was chosen from companies on the Ghana Stock Exchange. The research also adopted a quantitative research approach to offer a description of SEAR on companies and its effect on a company's financial performance in Ghana.

\subsection{Populations of the Study}

The population comprised of all the listed companies on the Ghana Stock Exchange as at the period of 2015-2017. The study employed a census approach; all companies listed on the GSE formed units of study. The selected period under review was a two year period; 2015 to 2018. In all, there are 43 companies listed on the Ghana stock exchange. The list of the companies is displayed in the appendix.

\subsection{Data Collection Instruments}

Questionnaires were utilized to collect primary data from the managers, accountants, and directors to gather information on Social and Environmental actions within the company and the perceptions towards the reporting CSR in SEA practices. A secondary data were had from the company's annual financial report on the Ghana Stock exchange as at 2015-2017. The questionnaires on the study were tested earlier before it was deployed to respondent for readability and validity. The questionnaire was given to professionals such as accountants, marketing managers, and directors to evaluate them for quality research to enrich the degree of satisfied validity, for important measurement of the aims of the study, therefore extraneous items were disregarded before it was distributed.

The first section of the questionnaires consists of the profile of the respondent. The second section of the questionnaires deals with CSR in SEA areas in which companies are involved. The final section deals with the relevance of including CSEA practices and the reasons for making such disclosure in the corporate policy. It is worthy to state that, some of the declarations in the last part were implemented from previous studies (Idowu \& Papasolomou, 2007; Al-Khater \& Naser, 2003). The second segment of the questionnaire utilized two response formats (yes/no), not solitary for corresponding the answer format to the thoughtful of evidence vital but also for directing response bias. The last section employed a multiple-choice setup where participants were mandated to indicate as numerous options as appropriate and applicable. This assisted to prevent biased answers.

\subsection{Data Analysis}

The study used cross-sectional multiple regression model in the analysis of the effects of CSEA on the financial performance in Ghana and is given by:

$$
\begin{gathered}
R O A=\alpha_{0}+\alpha_{1} \operatorname{COMTYINT}_{1}+\alpha_{2} \text { EMPCN }_{2}+\alpha_{3} \operatorname{CUSCN}_{3}+\alpha_{4} \text { ENVMN }_{4}+\alpha_{5} E_{N G S V G}+\alpha_{6} \text { EFFY }_{6}+ \\
\alpha_{7} \text { CAPINT }_{7}+\varepsilon_{t}
\end{gathered}
$$

Where ROA = Return on Assets as at 2015 -2017 of the companies;

COMTYINT = is community involvement;

$\mathrm{EMPC}=$ is Employees Concern;

CUSCN= Customer Concern;

ENVMN= Environmental;

ENGSVG= energy savings;

$\mathrm{EFFY}=$ Efficiency;

CAPINT= Capital Intensive;

The dependent variable is the Return on Assets which is given by ROA $=\frac{\text { NETINCOME }}{\text { TOTAL ASSETS }}$. 
Where net income can be seen on the Income statement, it can also be profit after tax on profit and loss account. Total Assets is made up non- current assets and current assets and can be found on the balance sheet. The key independent variables of the study were represented by CSR in Social and environmental disclosure: community involvement, employees Concern, customers concern, and others. Others made up of all those other activities of CSR which could not be attributed to any of the identified categories. Content analysis was used to determine the score for CSR based on the number of sentences dedicated to each component of CSR in the company's annual reports.

To secure robustness of the model for the study and for description bias, the model involved the resulting variables to control the bias of the model. The variables are efficiency and capital intensive. The efficiency is calculated by the COSTOF SALES

Capital Intensive is also given by $\frac{\text { TOTAL ASSETS }}{\text { TOTAL SALES }}$

\subsection{Measurement of Corporate Social and Environmental Accounting Reporting}

In measuring the content of the listed companies on Ghana stock exchange SEA information reporting's, content analysis was used. Content analysis is a frequently used method by most researchers in assessing companies SEA reporting (Humanyu \& Akinnusi, 2012). (Krippendorff, 1980, p. 21) as cited in Deengen (2017) states that "content investigation is an exploration system for making replicable and substantial surmising from information as indicated by their specific circumstance". In content analysis, distinguish methods are utilized in assessing the SEA reporting disclosures in so many studies on CSEA reporting. For the purpose of this study, the used of content analysis were based on choosing the appropriate documents for the content analysis, determining the appropriate unit of measuring the content analysis and the appropriate unit of measuring the level of social and environment accounting is the number of words as it is been used in most literature. The study finally identified the major categories of social and environmental and accounting reporting in Ghana, namely, energy savings, environmental, human resources, products and safety, and community involvement.

\section{Data Presentation, Analysis, and Discussions}

\subsection{Descriptive Analysis}

The descriptive analysis gives and discourses the data had from the structured questionnaires. (Primary data). One-hundred-thirty (130) respondents were contacted on the 43 listed companies on Ghana Stock Exchange, with three respondents from each company. Out of the 130 respondents, 125 respondents representing 95 percent rate partaken in this study of which the targeted respects were accountants, managers, and managing directors. Fifty-seven percent of the respondents had at least fifteen years' working experience. Summary of these findings are shown below in table 1 .

Table 1. Respondent demographic profile

\begin{tabular}{llll}
\hline Description & & Percentages & Number \\
\hline Gender & Male & 53 & 69 \\
& Female & 43 & 56 \\
\hline Age Group & $<30$ years & 21 & 27 \\
& 31-40 years & 54 & 70 \\
& 41-60years & 25 & 33 \\
\hline Edu. Qualification & Bachelor & 35 & 44 \\
& masters & 30 & 39 \\
& Professional Certification & 33 & 42 \\
\hline Year of Employment & $<5$ years & 16 & 20 \\
& 6-10 years & 17 & 21 \\
& 11-15 years & 57 & 70 \\
& $>16$ years & 11 & 14 \\
\hline
\end{tabular}

\subsection{Areas, Format and Adoption of Social and Environmental Accounting Practices}

Respondents were asked on whether their organizations indulged in SEA practices and the areas, format used in CSEA reporting practices. 
Table 2. Adoption of social and environmental accounting reporting according to respondents

\begin{tabular}{|c|c|c|c|c|}
\hline \multirow[t]{2}{*}{ Years } & \multirow{2}{*}{$\begin{array}{c}\text { Adoption } \\
\text { Frequency }\end{array}$} & \multirow[t]{2}{*}{ No Adoption } & \multicolumn{2}{|c|}{ Percentages $(\%)$} \\
\hline & & & Yes & No \\
\hline 2015 & 85 & 81 & $85 \%$ & $31 \%$ \\
\hline 2016 & 65 & 44 & $62 \%$ & 34 \\
\hline 2017 & 89 & 36 & $69 \%$ & $28 \%$ \\
\hline
\end{tabular}

It can be seen from the table that, 65 percent of companies on the Ghana Stock Exchange is practicing social and environmental activities in 2015, 62 percent in 2016 and 69 percent in 2017 respectively. Therefore, the course of the adoption of the SEA is above 60\%, and there has been an improvement from 2015 to 2017. It is evident that Ghanaian companies are hugging social and environmental accounting reporting practices.

Table 3. The areas of SEAR reported according to respondent

\begin{tabular}{lccc}
\hline Areas Reported & Number of Respondents & Mean & Percentages \\
\hline Environmental & $71(125)$ & $4.25(3)$ & 57 \\
Human Resources & $77(125)$ & $4.70(2)$ & 61 \\
Consumer Product & $51(125)$ & $3.65(4)$ & 41 \\
Community Involvement & $91(125)$ & $5.21(1)$ & 72 \\
Energy saving & $10(125)$ & $2.45(5)$ & 8 \\
\hline
\end{tabular}

From table 3 above, community involvement was rated as highest area reported according to the respondent. It is obvious that less heed was given by companies on categories such as environmental, human resources, consumer product, and energy saving. However, 60 respondent representing 48 percent admitted that their companies are engaged in CSR reporting practices. This comes with a terrific indication for most developing and emerging economies especially Ghana and this engagement is uniform with legitimacy theory which postulates that the performance and the longevity of a company in part are dependent on the assistant it receives from the society (Diez-Martin et al., 2013; Chelli et al., 2014). That is operating within the frontiers and via the norms of their respective society. Besides, companies in Ghana engagement in CSR reporting practices may adhere to the institution of SEAR which will fortify companies to be socially and environmentally responsible.

Table 4. The format for reporting social and environmental accounting

\begin{tabular}{lcc}
\hline & Reporting Format (2015) & \\
\hline & Monetary & Non- monetary \\
\hline Frequency & 99 & 25 \\
Percentage (\%) & 79 & 21 \\
\hline & Reporting Format (2016) & \\
\hline & Monetary & Non- monetary \\
\hline Frequency & 99 & 26 \\
Percentage (\%) & 79 & 25 \\
\hline & Reporting Format (2017) & \\
\hline & Monetary & 25 \\
Frequency & 100 & 20 \\
Percentage (\%) & $\mathbf{8 0}$ & \\
\hline
\end{tabular}

Respondents were examined on the format used in reporting social and environmental reporting on their annual reports. According to the respondents, $79 \%$ of companies adopted SEAR disclosed SEA information using the monetary form in $2015,79 \%$ in 2016 and $80 \%$ in 2017 respectively. Though, $20 \%$ of companies reported their SEA information utilizing non-monetary form in the year 2015, $21 \%$ in 2016, and $20 \%$ in 2017 . This clearly indicates that companies listed on the Ghana stock exchange still utilizes the descriptive format of disclosing the type of detailing (non-monetary on their CSR exercises instead of monetary reporting.

\subsection{The Extent of Corporate Social Responsibility Information Disclosures}

As stated untimely, content analysis was used in measuring CSR information practices. With this, the number of words was used to measure the extent of the corporate social responsibility information of the company's annual reports. 
Table 5. Extent of social and environmental accounting reporting

\begin{tabular}{lccccccc}
\hline \multirow{1}{*}{ AREAS } & \multicolumn{2}{c}{2015} & \multicolumn{2}{c}{$\mathbf{2 0 1 6}$} & \multicolumn{2}{c}{$\mathbf{2 0 1 7}$} & 3 years \\
\cline { 2 - 7 } & Words & Frequency & Words & Frequency & words & Frequency & Percentage \\
\hline Environmental & 213 & 8 & 412 & 9 & 472 & 10 & 11.6 \\
Human Resource & 901 & 10 & 1002 & 11 & 1020 & 11 & 31 \\
Consumer Product & 245 & 7 & 310 & 8 & 375 & 8 & 9.7 \\
Community Involvement & 1000 & 13 & 1310 & 10 & 1720 & 11 & 43 \\
Energy Savings & 76 & 5 & 180 & 5 & 191 & 3 & 4.7 \\
Aggregate. & 2,435 & 43 & 3,214 & 43 & 3,778 & 43 & 100 \\
\hline
\end{tabular}

The table depicted above gives the extent which companies reported their social responsibility in the annual financial report in Ghana. It can be seen that community involvement accounted for the utmost percentage of total reporting across the 3 years spell of the research. Over the three (3) years period, community involvement reporting with a total of 4,030 words representing 43 percent of the total Social Responsibility information disclosures. It is followed by human resources disclosures which accounted for 31 percent of the total CSR disclosures and environmental disclosures as the third ranked category which accounted for almost 12 percent of the total corporate social responsibility disclosure over the past three years. The least ranked area of social reporting based of the findings of the above table is energy savings with a percentage of five (5). Community involvement has enveloped the matters of aids of cash, employee's services to sustain community activities, occasions, organizations, education, public health projects, maintaining cultural legacy, girl child education and society campaigns about HIV/AIDS.

This is in accord with the estimates of stakeholder and legitimacy theories respectively.

Human resources reporting in Ghana which placed second covered areas on employee health and safety, employee training and development, bonus to personels, and recreation undertakings Environmental accounting reporting is the third categorized of reporting across the three year period. The environmental accounting reporting deals with fire extinguishers and fire exits, water treatment plant, safety training programmes, first aid kit, strewing warnings/facilities, air pollution control, job-related health and safety officers, environmental educational programmes, and clean-up-campaign programmes. From table 5, environmental disclosure expanded across the three-year spell of study and it is reliable and conclusive concerns that companies in Ghana are recognizing their responsibility to the environment. Energy saving been ranked as the least concerns of CSR and is the conservation policies, energy efficiency of products, and other energy-related reporting issues were monitored under "energy saving disclosure. Consumer product concerned matters regarding the inclusion of expiry dates on products, the recycling of waste goods, the disintegration of waste products, and discarding waste products in a neutral abode.

\subsection{Effects of SEAR on a Company's Financial Performance}

This section examines the effects of SEAR on a firm's financial performance using cross-sectional regression model. The theory highlighting the regression model were tested and the results are displayed below.

Table 6. Descriptive summary

\begin{tabular}{lccccc}
\hline Units & Observation & Mean & Minimum & Maximum & Standard Deviation \\
\hline ROA & 43 & 0.0773 & -0.1922 & 0.3318 & 0.0857 \\
CSR & 43 & 7.0777 & 6.1186 & 8.3279 & 0.4771 \\
EFFY & 43 & 0.7624 & 0.3961 & 0.9834 & 0.1372 \\
CAPINT & 43 & 1.3236 & 0.1697 & 0.2777 & 0.8275 \\
\hline
\end{tabular}

The above table (Table 6) shows the descriptive statistics of ROA, environmental, customer product, employees and community development represented by CSR, efficiency and capital intensive. An average ROA was 0.077 with a range of 0.1325 for the companies on their total assets of a minimum of 0.3318 . Meanwhile, the average $\log$ of CSR was 7.078 whiles efficiency and capital intensive were 0.76 and 1.32 respectively. 
Table 7. Correlation coefficient

\begin{tabular}{lcccc}
\hline & EEFY & CSR & CAPINT & ROA \\
\hline EFFY & 1 & & & \\
CSR & -0.3181 & 1 & & \\
CAPINT & 0.134 & -0.284 & 1 & \\
ROA & -0.417 & 0.19 & -0.46 & 1 \\
\hline
\end{tabular}

* The significant coefficient is at the 0.05 level (2-tailed).

The relationship between the variables was tested using person correlation. The statistical relationship between financial performance and corporate social and environmental accounting practices was at a significant level of 5 percent. It can be viewed from table 7 that, none of these variables were strongly correlated with each other.

Table 8. Results of the regression model 1

\begin{tabular}{cccc}
\hline Multiple R & R Square & Adj R-squared & Std. Error of Estimate \\
\hline 0.6751 & 0.451 & 0.431 & 1.008 \\
\hline
\end{tabular}

Table 9. ANOVA testing

\begin{tabular}{llllll}
\hline & $d f$ & $S S$ & $\boldsymbol{M S}$ & $\boldsymbol{F}$ & Prob $>\boldsymbol{F}$ \\
\hline Model & 40 & 56.112 & 18.712 & 18.375 & $.000 \mathrm{~b}$ \\
Residuals & 3 & 67.198 & 1.018 & & \\
Total & 43 & 123.31 & & & \\
\hline
\end{tabular}

Based on the findings shown, the independent variables indicates about $43 \%$ of the variations in ROA. However, F test was utilized to institute the statistical significance of the model. The outcome shows that the model was significant statistically and could give predictive value using all the independent variables in order to forecast the financial performance of Ghanaian listed companies $(F=18.375 ; p<0.05)$ (table 9) Besides, r-squared for the regression model was 0.451 (table 8 ) describing $45 \%$ of the change in listed companies performances.

Table 10. Significance of the variables

\begin{tabular}{lccccc}
\hline \multirow{2}{*}{ Model } & \multicolumn{2}{c}{ Unstandardized coefficient } & Standard coefficient & t & Sig. \\
\cline { 2 - 3 } & $\mathrm{B}$ & Stand. Error & Beta & & \\
\hline Constant & .277 & .544 & & 2.255 & .805 \\
Capital intensive & .399 & .872 & .711 & -3.611 & .073 \\
Efficiency & -.104 & .886 & .047 & -3.151 & .889 \\
CSR score & .271 & .405 & .193 & 1.033 & .564 \\
\hline
\end{tabular}

Note. The test of the statistical significance of the independent variables in the model was done using t-tests.

The objective was tested at a 5 percent significance level evaluate the significance of the variables (CSR, efficiency and capital intensive). This significance level shows that relationship exists between the variables (dependent and independent variables). As depicted in the table above (table 10), capital-intensive and efficiency were significant $(\mathrm{p}<0.05)$ thus describing that both had a significant effect on the company's financial performance. Findings, however, shows that social and environmental accounting practices: community involvement, consumer product, employees, environmental represented by CSR was not a significant factor in impacting company's financial performance ( $p>0.05)$.

Besides, capital-intensive specifies a significant facet in making clear the performance of the companies listed ( $\beta$ $=0.399 ; \mathrm{p}>0.05)$. This shows that capital intensive of companies reduces, their performance is positively affected and improves, making their performance negatively affected. Additionally, the results also showed that efficiency had a negative effect on the performance of firms, since $(\beta=-104 ; p<0.05)$. This means that refinement in efficiency would lead to the improvement in the financial performance of companies listed in the Ghana stock exchange. Meanwhile, the study further shown that SEA practices: community development, employees concern, consumer's product, environment issues represented by CSR score did not have any significant effect on the listed company's financial performance. $(\beta=0.271 ; p>0.05)$. This signals that the sum of money disbursed on social and environmental accounting practices does not significantly describe the 
financial performance of the corporation.

\section{Conclusions}

The study examined the effects of social and environmental accounting practices on the financial performance of listed firms of Ghana. The study assesses the areas of CSR issues reported and the format used in the annual financial reports of companies listed on Ghana Stock Exchange over the period of three years from 2015 to 2017. It finally documents the extent to which companies in Ghana included social and environmental accounting requirements in their corporate strategy policies.

From the study findings, it was found that there was a positive correlation between CSR score measuring the social and environmental accounting and company financial performance listed on the Ghana stock exchange. However, the effect was insignificant ( $\beta$ eta for CSR Score is $0.27 ;(\beta=0.271 ; p>0.05)$. This means that an increase in the SEAR would lead to an increased in firms financial performance. These findings agree (for example Ahmed, 2014 on the study conducted on companies listed in Bursa Malasia which was revealed that CSR was positively related with financial performance. For example, a study done by Wambui (2012) had similar results indicating corporate financial performance and CSR had a strong relationship.

In view of areas of CSR practices in which companies listed on Ghana exchange are involved, the findings reveals that community development involvement was the greatest area, followed by human resource while the least important area was on energy savings issues practiced. The results of the findings, however, depict that, companies listed on Ghana stock exchange report CSR issues discretionary but not authorized by any regulators in Ghana for reporting such issues on companies annual reports.

The study further shows that companies in Ghana are now hugging social and environmental accounting reporting practices since the course of adoption of the SEA was above 60\% from 2015 to 2017. (Table 2). Even though the disclosures do not follow any guidelines and mostly the disclosure was done on a non-monetary basis. (Table 4). The findings, however, show that community involvement was the most issues reporting as measured by the number of words, come behind is human resources, environmental while the least is energy saving related issues (Table 5). The research found that the increasing trend of CSR information reporting shows that corporations sense sine qua non of disclosing social practices. For example, a study done Humayun \& Akinnusi, (2012) in Switzerland, Ratanajongkol et al. (2006) found that community involvement had the highest issues disclosed measured by a number of words. However, in light of considering these studies, it is worthy to note that, these researchers did their studies with dissimilar sample sizes. As such, the data are not rigorously similar. The investigation found that in spite of the fact that there was a pattern of expanding CSR information reporting among corporations from 2015 to 2017, the total of average disclosure per disclosing company has not enlarged so much.

\section{Implications and Recommendation}

In light of the conclusions made in the studies above, there are a number of positive implications. It was evident that there is a positive correlation between social and environmental accounting and reporting and companies financial performance. Therefore, top managers in companies grasp and embrace social and environmental accounting and disclosures. In view of this, companies should be socially responsible in order to enlarge the value for the shareholders and other stakeholders. The findings also show in the study that, about 48 percent of companies in Ghana are indulged in voluntarily SEAR reporting practices but follows any recognized format. With this, social and environmental accounting practices should be viewed as authorized not to be voluntary in all companies in Ghana. There Ghana stock exchanges, Ministry of Finance, regulatory bodies and all stakeholders involved should mount policies among firms to ensure that, the firms act ethical and socially responsible manner to all stakeholder needs to be formulated and implemented. The regulatory bodies in Ghana such as GSE, capital market, has to bring out guidelines and requirements for firms in reporting social and environmental accounting practices.

The research concentrated on only companies listed on the Ghana stock exchange from the period of 2015 to 2017. Therefore, the ending arrived at should not be subjected to all industries, and developing countries since CSR practices are tedious and complex to described from one level of decision. (Gray et al., 1995a, p. 67)

\section{Future research}

Future studies could find the effects of SEA reporting issues on all companies in Ghana since there enormous companies working but not listed on the stock exchange. This could increase the sample size for better comprehension and irrefutable conclusion in regulating indeed that social and environmental accounting has an effect on the company's financial performance. 


\section{References}

Amaeshi, K. M., Adi, B. C., Ogbechie, C., \& Amao, O. O. (2006). Corporate social responsibility in Nigeria: Western mimicry or indigenous influences? Journal of Corporate Citizenship, 24, 83-99. https://doi.org/10.9774/GLEAF.4700.2006.wi.00009

Amran, A., \& Devi, S. S. (2008). The impact of government and foreign affiliate influence on corporate social reporting: The case of Malaysia. Managerial Auditing Journal, 23(4), 386-404. https://doi.org/10.1108/02686900810864327

Araya, M. (2006). Exploring terra incognita: non-financial reporting in Latin America. Journal of Corporate Citizenship, 21, 25-38. https://doi.org/10.9774/GLEAF.4700.2006.sp.00005

Bank of Ghana. (2016). Intelligence and Economic forum Report on Financial industries.

Belal, A. R. (2001). A study of corporate social disclosures in Bangladesh. Managerial Auditing Journal, 16(5), 274-89. https://doi.org/10.1108/02686900110392922

Belal, A. R., \& Owen, D. L. (2007). The views of corporate managers on the current state of, and future prospects for, social reporting in Bangladesh. Accounting, Auditing \& Accountability Journal, 20(3), 472-94. https://doi.org/10.1108/09513570710748599

Belkaoui, A., \& Karpik, P. G. (1989). Determinants of the corporate decision to disclose social information. Accounting, Auditing \& Accountability Journal, 2(1), 36-51. https://doi.org/10.1108/09513578910132240

Carroll, B. A. (2000). Ethical challenges for business in the new millennium: Corporate social responsibility and models of management morality. Business Ethics Quarterly, 10(1), 33-42. https://doi.org/10.2307/3857692

Crowther, D., \& Aras, G. (2009). Corporate social responsibility. Retrieved from http://bookboon.com/int/student/organization/defining-corporate-social responsibility

De Villiers, C. J. (1996). The awareness level of different stakeholder groups and their willingness to support corporate environmental reporting in South Africa. Doctoral dissertation, University of Pretoria, Pretoria.

Deegan, C. (2017). Twenty-five years of social and environmental accounting research within Critical Perspectives of Accounting: Hits, misses and ways forward. Critical Perspectives on Accounting, 43, 65-87. https://doi.org/10.1016/j.cpa.2016.06.005

Deegan, C., \& Gordon, B. (1996). A study of the environmental disclosure practices of Australian corporations. Accounting \& Business Research, 26(3), 187-99. https://doi.org/10.1080/00014788.1996.9729510

Deegan, C., \& Rankin, M. (1996). Do Australian companies report the environmental news objectively? An analysis of environmental disclosures by firms prosecuted successfully by the Environmental Protection Authority. Accounting, Auditing \& Accountability Journal, 9(2), 50-67. https://doi.org/10.1108/09513579610116358

Deegan. (2002). The legitimizing effect of social and environmental disclosures - a theoretical foundation. Accounting, Auditing \& Accountability Journal, 15(3), 282-311. https://doi.org/10.1108/09513570210435852

Egels, N. (2005). CSR in electrification of rural Africa: The case of ABB in Tanzania. Journal of Corporate Citizenship, 18, 75-85. https://doi.org/10.9774/GLEAF.4700.2005.su.00011

Enviroreporting.com. (2009). Development of sustainability guidelines for the agricultural sector is progressing. Retrieved from http://www.enviroreporting.com

Ernst \& Ernst. (1978). Social Responsibility Disclosure: Survey of Fortune 500 Annual Report. Ernst \& Ernst, Cleveland, $\mathrm{OH}$.

Fauzi, H., Mahoney, S., \& Rahman, A. (2007). The link between corporate social Performance and Financial performance: Evidence from Indonesian companies. Issues in Social and Environmental Accounting, 1(1), 145-159. https://doi.org/10.22164/isea.v1i1.12

Fig, D. (2005). Manufacturing amnesia: corporate social responsibility in South Africa. International Affairs, 81(3), 599-617. https://doi.org/10.1111/j.1468-2346.2005.00471.x

Gay, L. R., \& Diehl, P. (1992). Research Methods in Business and Management. Macmillan, New York, NY.

Gray, R., Owen, D., \& Adams, C. (1996). Accounting and Accountability. Prentice Hall, London.

Gray, R., Owen, D., \& Maunders, K. (1987). Corporate Social Reporting: Accounting and Accountability. 
Prentice Hall, London

Gupta, A. D., \& Gupta, A. D. (2008). Corporate social responsibility in India: towards a sane society. Social Responsibility Journal, 4(1/2), 209-16. https://doi.org/10.1108/17471110810856965

Hackston, D., \& Milne, M. J. (1996). Some determinants of social and environmental disclosures in New Zealand companies. Accounting, Auditing \& Accountability Journal, 9(1), 77-108. https://doi.org/10.1108/09513579610109987

Hamann, R., Kapelns, P., Sonnenberg, D., Mackenzie, A., \& Hollesen, P. (2005). Local governance as a complex system: Lessons from mining in South Africa, Mali and Zambia.

Humayun, K., \& David, M. A. (2012). Corporate social and environmental accounting information reporting practices in Swaziland. Social Responsibility Journal, 12(2), 156-173.

Idowu, S. O., \& Towler, B. A. (2004). A comparative study of the contents of corporate social responsibility reports of UK companies. Management of Environmental Quality: An International Journal, 15(4), $420-37$. https://doi.org/10.1108/14777830410540153

Islam, M. A., \& Deegan, C. (2007). Motivations for organizations within developing countries to report social responsibility information: A case study from Bangladesh. Paper presented at the Fifth Asia Pacific International Research in Accounting Conference, Auckland, July 8-10.

KPMG. (2005). International Survey of Corporate Responsibility Reporting (Vol. 2005). KPMG, Amsterdam.

Kuasirikun, N., \& Sherer, M. (2004). Corporate social accounting disclosure in Thailand. Accounting, Auditing \& Accountability Journal, 17(4), 629-60. https://doi.org/10.1108/09513570410554588

Lehman, G., \& Kuruppu, S. C. (2017). A framework for social and environmental accounting research. Accounting Forum, 41(3), 139-146. https://doi.org/10.1016/j.accfor.2017.07.001

Mathews, M. R. (1997). Towards a Mega- Theory of accounting. Asia-Pacific Journal of Accounting, 4(2). https://doi.org/10.1080/10293574.1997.10510524

Mohtar, R. H. et al. (2019). Economic, social, and environmental evaluation of energy development in the Eagle Ford shale play. A Science of the Total Environment, 646, 1601-1614. https://doi.org/10.1016/j.scitotenv.2018.07.202

O'Donovan, G. (2002). Environmental disclosures in the annual report: Extending the applicability and predictive power of legitimacy theory. Accounting, Auditing \& Accountability Journal, 15(3), $344-71$. https://doi.org/10.1108/09513570210435870

Ofori, D. F., \& Hinson, R. E. (2007). Corporate social responsibility (CSR) perspectives of leading firms in Ghana. Corporate Governance, 7(2), 178-93. https://doi.org/10.1108/14720700710739813

Pratten, J. D., \& Mashat, A. A. (2009). Corporate social disclosure in Libya. Social Responsibility Journal, 5(3), 311-27. https://doi.org/10.1108/17471110910977258

Raman, S. R. (2006). Corporate social reporting in India - A view from the top. Global Business Review, 7 , 313-24. https://doi.org/10.1177/097215090600700208

Ratanajongkol, S., Davey, H., \& Low, M. (2006). Corporate social reporting in Thailand. Qualitative Research in Accounting \& Management, 3(1), 67-83. https://doi.org/10.1108/11766090610659751

Registrar of Companies. (2015). Company Registration Database. Office of the Registrar of Companies, Government of Ghana, Accra.

Rob, G., Colin, D., Dave, O., Richard, E., \& Simon, Z. (1997). Struggling with the proxis of social accounting. Accounting and Auditing.

Ruiz-Mora, I., \& Guerrero-Navarro, D. (2018). Resposnsilidad Social en el futbol professional espanol, Una relacion para el desarrollo de un Nuevo ciudadno.

Said, R., Zainuddin, H. Y., \& Haron, H. (2009). The relationship between corporate social responsibility disclosure and corporate governance characteristics in Malaysian public listed companies. Social Responsibility Journal, 5(2), 212-26. https://doi.org/10.1108/17471110910964496

Savage, G. T., Nix, T. W., Whitehead, C. J., \& Blair, J. D. (1991). Strategies for assessing and managing organizational stakeholders. Academy of Management Executive, 5(2), 61-75. 


\section{Appendix 1. List of companies registered on Ghana stock exchange}

\begin{tabular}{llllll}
\hline Symbol & Name of Company & Symbol & Name of Company & Symbol & Name of Company \\
\hline ACESS & Access Bank Limited & ETI & Eco bank Trans nation Corporation & PBC & Produce Buying Company \\
ACI & Africa Champions Industries & EGL & Enterprise Group Ltd. & PZC & PZ Cussons Ghana Ltd. \\
ADB & Africa Development Bank & FML & Fan Milk Ghana & RBGH & Republic Bank Ghana Ltd. \\
AWL & Aluworks Limited & GCB & Ghana Commercial Bank & SWL & Sam wood Ltd. \\
ADDs & AgloGold Ashanti & GOIL & Ghana Oil Company Ltd. & SAMBA & Samba Food Ltd. \\
ARTYN & Ayton Drugs Manufacturing & GST & Golden star Resources & SIC & SIC companies Ltd. \\
BOPP & Benso Palm Plantation Ltd. & GGBL & Guinness Ghana Brewery Ltd. & SOGGH & Societe General Bank Ltd. \\
CAL & Cal Bank Limited & HORDS & Hords Limited & SCB & Standard Chartered Bank S \\
CMLT & Camelot Ghana Limited. & MLC & Mechanical Lloyd Company Plc. & SCBPREF & Standard Chartered Bank \\
CLYD & Clydestone (Ghana) Ltd. & MAC & Mega Africa Capital Ltd. & SPL & Starwin Products Limited \\
CPC & Cocoa Processing Company & MMH & Meridian-Marshalls Holdings & TOTAL & Total Petroleum Ghana Ltd. \\
CPL & Comet Properties Limited & MTNGH & MTN Ghana & TBL & Trust Bank Limited \\
DIGICUT & Digicut Advertising and processing & GLD & New Gold Issuer Ltd. & TLW & Tullow oil Plc \\
EGH & Eco bank Ghana Ltd. & PKL & Pioneer Kitchenware Limited & UNIL & Unilever Ghana Ltd. \\
\hline
\end{tabular}

\section{Copyrights}

Copyright for this article is retained by the author(s), with first publication rights granted to the journal.

This is an open-access article distributed under the terms and conditions of the Creative Commons Attribution license (http://creativecommons.org/licenses/by/4.0/). 